\title{
Cytotoxic activity of Cardia draba leaves extracted on some cancer cell line
}

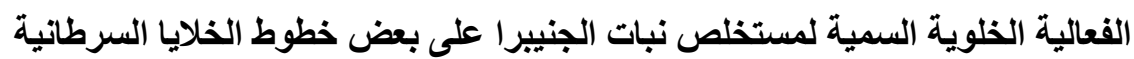

Shymaa I. Albarazanchi Faik Ibrahim Ali* Ahmed F. Alshanon**

Pharmacological College /Al-Nahrain University

Biology Department/Education College /Tikrit University*

Biotechnology Research Center /Al-Nahrain University**

شيماء عصام البرزنجي فائق ابراهيم علي * احد فاضل الثنون**

كلية الصيدلة /جامعة النهرين

*قمب علوم الحياة /كلية التربية /جامعة تكريت * ق

مركز بحوث التقنيات الاحيائية /جامعة النهرين**

E-mail: Hamudi7787@gmail.com

\section{Abstract}

Cardaria draba is considered as one of the most fundamental plants that have wide diversity in medical uses, other researches had shown that this plant has a strong antioxidant activity for this reason the idea came to look for the cytotoxicity of this plant extract against different carcinogenic cell lines after subjection of this plant to methanolic extraction method.Result declared strong cytotoxicity against those carcinogenic cell line with a variable values of $\mathrm{IC}_{50}$ and the best effect was seen against HepG2 cell line, then we looked for the reason behind this reduction in viability of the cells via performing Caspase 9 assay which is used to check the induction of apoptosis and the expression of the TNF- $\alpha$ as a strong transcription factor which is activated in tumor cell lines.

Interestingly, our finding suggested that the plant extract produced a positive effect in the induction of Caspase 9 which led to induce early apoptosis, regarding TNF- $\alpha$ expression; the result explained a significant reduction in expression of those genes which were correlated with induction of tumor. This meant that the reduction in cell viability resulted in the induction of apoptosis and reduction of TNF- $\alpha$ transcription genes.

Key word: Cardia draba , tumor cell lines

يعتبرنبات الجنيبرا من النباتات التي تستخدم بثكل واسع في المجال الطبي .اشارت البحوث ان هذان هذا النبات له فعالية قوية مضادة

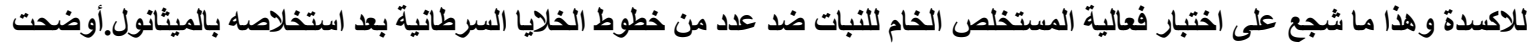

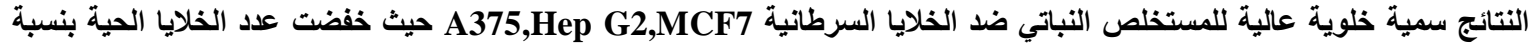
تراوحت بين 40-60\%,وأفضل تأثير ظهر على الخلايا السرطانية للكبد Hep G2 ب 53,2 Ic50 مايكروغرام/مل .كما وتم دراسة

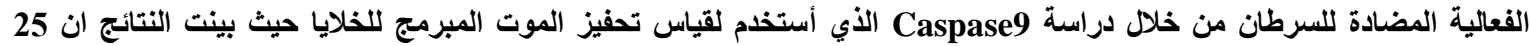

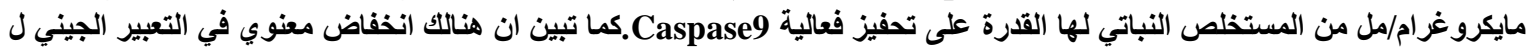
TNF-a

الكلمات المفتاحية: جنيبرا ، مضادات السرطان ، الموت المبرمج للخلية 


\section{Introduction}

It's well-known that medical plants are considered as one of the most important sources used for the production of drugs and other medical components. The importance of these plants came those active compounds which play substantial role in pharmaceutical production, should undergo certain biological check for other effects when we want to use them on different applications on cell lines like; cytotoxicity and antioxidant to ferret if there is any side effect upon their uses[1].

The focused on Cardaria Graba, this plant is about 10- $80 \mathrm{~cm}$ length, with white top end with horizontal creeping roots, the stem is branched while leaves are simple, alternating and mostly toothed. The size of leaves of this plant is about 4- $10 \mathrm{~cm}$, with slight stem. While its shape is either lance or egg-shaped. This plant is found normally in southern part of Europe and eastern part of Asian, but it is rarely found in North America, other findings refer to its presence in Australia[2].

For many years, it was well known that medical plants had been used for treating against different types of diseases and cancers that helped in supporting the body to resist any defect that lead to the discovery of new medicine[3,4]. The development of information and knowledge in medicinal plant which came from many experimental trials and that helped in appearance of many traditional, famous therapies like; Chinese medicine, naturopathy, and aromatherapy[5,6,7]

For this reason, the natural drugs are considered as a fundamental source for such treatment and considered as an alternative mean for the treatment of any infection beside the chemical drugs [8,9]. The practical application of herbal medicine came to support other types of medicine due to its importance in treatment of bacterial diseases $[10,11,12]$.

\section{Materials and Methods}

\section{Plant collection}

The leaves of Cardaria Graba were collected in March-April 2016 from Al- Khalidia near Baghdad. The classification of plant based on the morphological characteristics in the department of biology/Baghdad University. Then materials were air-dried at room temperature under shade for 8-10 days. The dried leaves were pulverized to powdered form by mortar and pestle. The powdered form was then stored at room temperature

\section{Plant extraction}

Dried plant material $(10 \mathrm{~g})$ was extracted with $100 \mathrm{ml}$ of methanol using rotary shaker for $24 \mathrm{~h}$. Later on, it was filtered and centrifuged at $5000 \mathrm{~g}$ for $15 \mathrm{~min}$. After evaporation of the solvent, the supernatant was collected to make the final volume one-fifth of the original volume. It was stored at $4^{\circ}$ in bottles for further experiment[13].

\section{Viability assay}

Protocol was performed following the manufacturer instructions. Cells $\left(1 \times 10^{4}-1 \times 10^{6}\right.$ cellsmL $\left.{ }^{-1}\right)$ were grown in a 96 flat-well plate, with a final volume of $200 \mu \mathrm{L}$ per well. The plate was covered by sterilized parafilm, agitated gently, and incubated at $37 \pm{ }^{\circ} \mathrm{C}, 5 \% \mathrm{CO}_{2}$ for $24 \mathrm{~h}$. After incubation, the medium was removed and $200 \mu \mathrm{L}$ of the two fold serial dilutions of $P$. graveolens crude extract $(25,50,100,200,400$ $\mu \mathrm{gmL}^{-1}$ ) were added to the wells. Triplicates were performed at each concentration, as well as controls. Plates were incubated at $37 \pm{ }^{\circ} \mathrm{C}, 5 \% \mathrm{CO}_{2}$ for $24 \mathrm{~h}$. After exposure to extract, $10 \mu \mathrm{L}$ of the MTT solution was added to each well. Plates were further incubated at $37 \pm{ }^{\circ} \mathrm{C}, 5 \% \mathrm{CO}_{2}$ for $4 \mathrm{~h}$. The medium was then carefully aspirated and $100 \mu \mathrm{L}$ of solubilization solution was added per well and incubated for $5 \mathrm{~min}$. The absorbance was determined with an ELISA reader (Bio-Rad - Germany) at a wavelength of $575 \mathrm{~nm}$. For calculation of IC 50, the optical density readings were subjected to statistical analysis[14].

\section{RNA isolation, cDNA synthesis and rt PCR}


RNA isolation was from infected cells was implemented using the RNeasy Mini Kit or RNeasy Plus Mini Kit (Qiagen) according to the manufacturer's protocol as mention[15]. Concentration of purified total RNA was measured by a Nanodrop ND-1000 spectrophotometer (Peqlab). Then, equal amounts of RNA were used to synthesize cDNA using Thermo Fisher Scientific kit according to the manufacturer's protocol. The quantification of cDNA was performed by quantitative real-time polymerase chain reaction (qRT-PCR) and the following primers: GAPDH_fwd 5'-gcaaattccatggcaccgt-3', GAPDH_rev 5'- gccccacttgattttggagg-3', TNF_fwd 5'- CTGCTGCACTTTGGAGTGAT-3',TNF_rev5'AGATGATCTGACTGCCTGGG-3'.The qRTPCR reaction mix (Brilliant III SYBR Green QPCR Master Mix) was purchased from Agilent Technologies. Analysis was performed as described earlier, the GAPDH primers used as a control to calculate the CT values [16].

\section{Caspase 9 activity}

A time-dependent study of caspase -9 activities was done three times using assay kits Caspase-GloH 9 (Promega, Madison, WI) on our cell lines using a 96-well microplate. A total of $1 * 10^{4}$ cells $/ \mathrm{ml}$ was seeded and incubated with $100 \mathrm{ml}$ of methanolic plant extract at different concentration as mentioned in results for 24 hours. Caspase activities were performed according to the manufacture protocol. Briefly, $100 \mathrm{ml}$ caspaseGlo reagent were added and incubated at room temperature for 30 minutes. The activity of caspases from apoptotic cells cleaved the aminoluciferin-labeled synthetic tetrapeptide and led to the release of substrate for the luciferase enzyme. For measurements, we used a Tecan InfiniteH200 Pro (Tecan, Ma“nnedorf, Switzerland) microplate reader [17].

\section{Cell lines}

Different cell lines had been used to accomplish this research; Hepatobastoma (HepG2) cells[18], Human breast adenocarcinoma (MCF-7) cells[19], Human malignant melanoma cell (A375) line[20] and WRL68 cell line as normal cell line were obtained from American Type Culture Collection (ATCC) and cultured in DMEM medium supplemented with $10 \%$ Fetal Bovine Serum, 1\% sodium bicarbonate, $10^{3}$ IU Penicillin G, and $100 \mu \mathrm{gmL}^{-1}$ Streptomycin. MCF-7 cells were maintained in $\mathrm{CO}_{2}$ incubator $(5 \%)$ at $37 \pm^{\circ} \mathrm{C}$.

\section{Statistical Analysis}

In this research, one way analysis of variance (ANOVA) was performed to analyze all data. Those were standard deviation (SD) and statistical significances were carried out using a GraphPad \pm expressed as mean Prism version 6.

\section{Results}

\section{Cytotoxic Effects of C.draba Extracts on different carcinogenic cell lines using the MTT Assay:}

MTT assay is considered as fundamental way used to determine the cytotoxic activity of different plant extracts among them; our methanolic extract from Cardaria draba plant. Here, we tested the cytotoxic effect of this extract against different carcinogenic cell lines like; Hepatobastoma (HepG2) cells, Human breast adenocarcinoma (MCF-7) cells, Human malignant melanoma cell (A375) line While, WRL68 cell line was used as normal cell line. The purpose of this assay is to determine the cell viability and the inhibition rate via using different concentrations of Cardaria draba plant extract on these cell lines as mentioned in table1.

Those results represented the effect of treatment of tumor cell line with different concentrations started with 6.2 and ended with $400 \mu \mathrm{gmL}^{-1}$ and $\log$ values of $\mu \mathrm{gml}^{-1}$ was performed on a Graphpad Prism 6 using $\log$ (Inhibitor) versus response curve.

It is well known that the most effective concentrations were selected depending on the most significant and lowest $\mathrm{IC}_{50}$ values. Cell viability at each time-point was determined by MTT colorimetric assays.

Figure 1(a) which represents the MTT assay on WRL 68 cell line which is considered as normal cell line and it is considered as a control test while figures $1(\mathrm{~b}, \mathrm{c} \& \mathrm{~d})$ showed as different expressions and values from the exposure of HePG2, MCF7 and A375 cell lines respectively to the methanolic extract of Cardaria Graba at different concentrations started from 6.2 till $400 \mu \mathrm{gml}^{-1}$. 
In figure 1 (b,c \& d); we could see certain differences of vibrations in reduction rate or cell viability upon using our extract on different tumor cell lines 24 hours post the treatment, the cell viability decreases upon increasing the concentrations in those cell lines. The lowest reduction rate between all cell lines ranged from 40- $60 \%$, while most effective cytotoxic effect which had shown the lowest $\mathrm{IC}_{50}$ was 53.2 in HePG2 cell lines.

IN A375 and MCF 7, we got clear reduction in cell viability upon treatment with plant extract, but the $\mathrm{IC}_{50}$ that we got were 100 and 80 respectively. This means that the plant extract produced higher cytotoxic effect on other cells. For this reason we selected HepG2 cells for further studies had shown higher values compared with HepG2 cells.

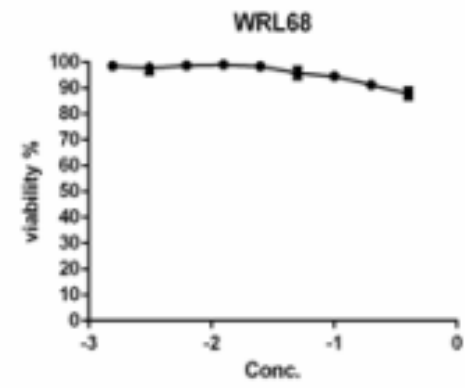

A

IC $50=80$

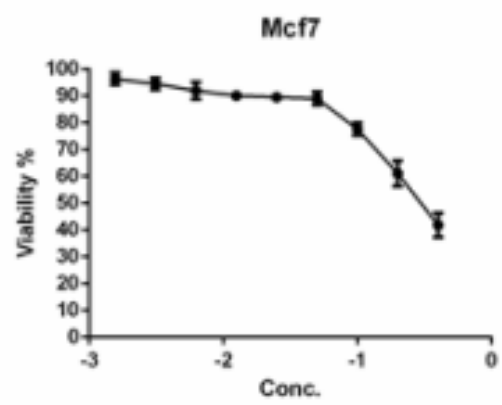

C

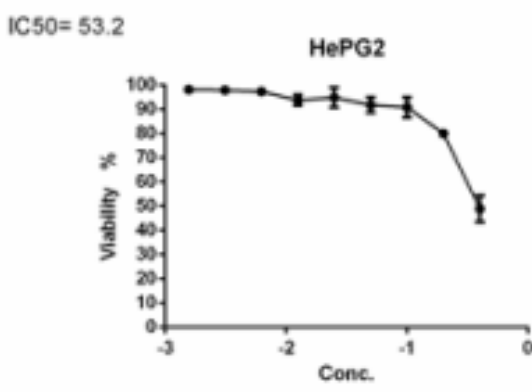

B

IC $50=100$

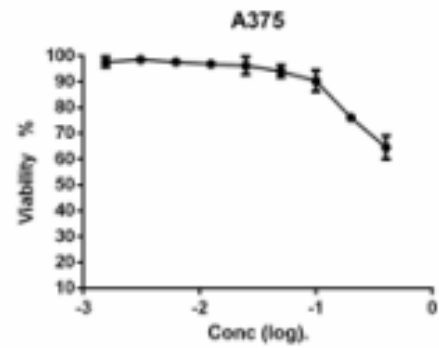

D

Figure( 1): cytotoxic activity of methanolic extract of Cardaria Graba on different tumor cell lines like; A735,

HePG2, MCF-7 and WRL as normal cell line using different concentrations represented by log values and calculated by ug/ml, while cell viability are calculated by percentage as shown in figure's legends. 
Table (1) : represents the count of viable cell no. upon the treatment of Cardaria Graba extract on different tumor cell lines.

\begin{tabular}{lcrrr}
\hline Treatment $(\mu \mathrm{g} / \mathrm{ml})$ & $\begin{array}{c}\text { Viable Cell Count } \\
\text { HepG2 } \\
(\text { Mean } \pm \text { SD) }\end{array}$ & $\begin{array}{c}\text { Viable Cell Count } \\
\text { MCF7 } \\
(\text { Mean } \pm \text { SD) }\end{array}$ & $\begin{array}{c}\text { Viable Cell Count } \\
\text { A375 } \\
(\text { Mean } \pm \text { SD) }\end{array}$ & $\begin{array}{c}\text { Viable Cell Count } \\
\text { WRL } \\
(\text { Mean } \pm \text { SD) }\end{array}$ \\
\hline 400 & $48.9 \pm 5.4$ & $41.8 \pm 4.5$ & $64.5 \pm 4.5$ & $87.8 \pm 2.1$ \\
200 & $80.1 \pm 1.8$ & $61.1 \pm 4.7$ & $76.0 \pm 1.3$ & $91.0 \pm 0.7$ \\
100 & $90.8 \pm 4.2$ & $77.6 \pm 2.3$ & $90.3 \pm 4.1$ & $94.6 \pm 1.3$ \\
50 & $91.8 \pm 3.0$ & $89.0 \pm 2.2$ & $94.0 \pm 2.3$ & $96.8 \pm 2.1$ \\
25 & $94.9 \pm 4.0$ & $89.5 \pm 1.9$ & $96.2 \pm 3.4$ & $98.4 \pm 0.7$ \\
12.5 & $93.7 \pm 2.2$ & $90.1 \pm 0.4$ & $96.8 \pm 1.4$ & $99.1 \pm 0.9$ \\
6.25 & $97.7 \pm 1.2$ & $91.9 \pm 3.1$ & $97.7 \pm 0.3$ & $98.7 \pm 0.6$ \\
3.125 & $97.9 \pm 1.5$ & $94.5 \pm 2.1$ & $98.6 \pm 0.7$ & $97.8 \pm 2.2$ \\
1.5625 & $98.1 \pm 0.6$ & $96.4 \pm 2.3$ & $97.6 \pm 2.0$ & $98.6 \pm 1.0$
\end{tabular}

\section{Plant extract induces Caspase 9 activity significantly}

Its well-known that apoptosis is considered as complicated activity that mobilize no. of molecules, the caspase activity is a good mean to determine such activity. Here we tested the effect of our plant extract on HePG2 cell line because, it had shown the lowest $\mathrm{IC}_{50}$ compared with other cell line used in this research. To study the apoptotic activity, we stained the cells with aminoluciferin labeled substrate of caspase to determine the caspase 9 via the estimation of intensities of illumination after 24 hour post labeling. We noticed a graduated increase in caspase activity in $\mathrm{HePG} 2$ cells that was labeled with illuminant and treated with our plant extract,

At $25 \mu \mathrm{g} / \mathrm{ml}$, we found significant increase in Caspase 9 compared with control sample and this activity increased more upon increasing the concentration of plant extract with $50 \mu \mathrm{g} / \mathrm{ml}$ The maximum level of caspase had been detected upon the treatment with maximum concentration of our plant extract which was $100 \mu \mathrm{g} / \mathrm{ml}$ indicating that this plant extract is a good or strong activator for caspase activity in tumor cell line as shown in figure 2 


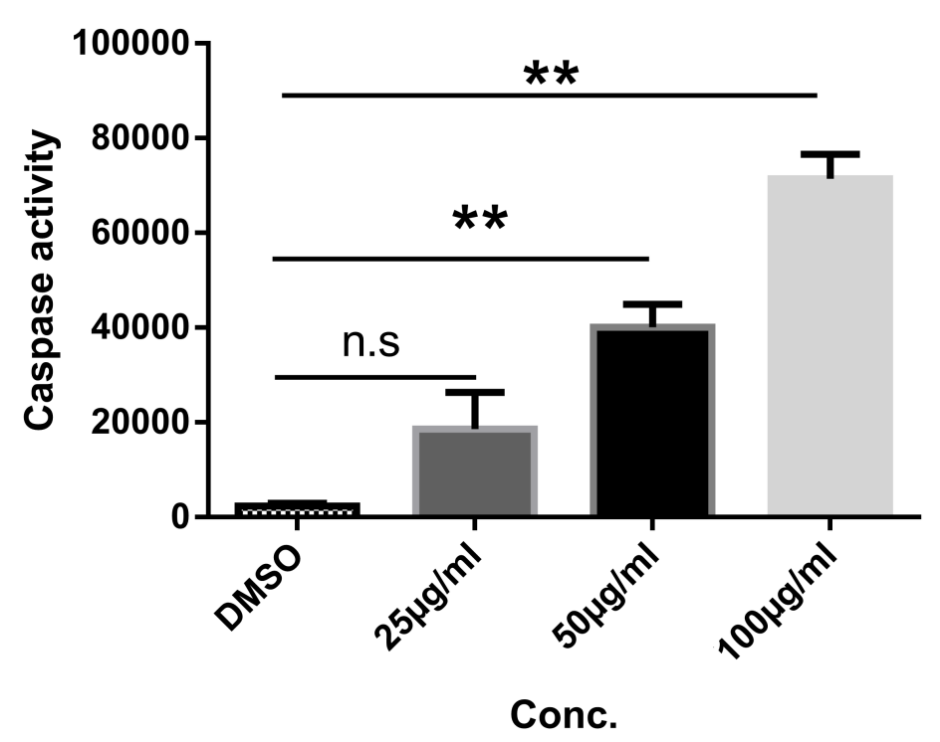

Figure (2): activation of caspase activity by plant extract. Results were normalized with DMSO values as fold of increase compared with control. Data represents mean \pm SD of three independently repeated experiments. One way Anova followed by Dunnett's multiple comparison test using DMSO as a control used for statistical analysis of each time point separately $(* * p \leq 0.01)$.

\section{Plant extract reduces TNF- $\alpha$ activity}

To speculate about the role of plant extract on TNF activity, we treated our cell line with different concentration of plant extract $(25,50$ and $100 \mu \mathrm{g} / \mathrm{ml})$ then; we checked the activity of TNF- $\alpha$ by real time PCR after extraction of cDNA.

The results were shown certain reduction in TNF- $\alpha$ activity in treated cells compared with control, TNF- $\alpha$ expression started to decrease when the cell line was treated with $25 \mu \mathrm{g} / \mathrm{ml}$ of the extract. Interestingly, this reduction increased more upon using a concentration of $50 \mu \mathrm{g} / \mathrm{ml}$ till getting a highly significant decrease in expression of TNF- $\alpha$ when we used $100 \mu \mathrm{g} / \mathrm{ml}$ of the plant extract.

Our finding indicates that this extract showed us a positive effect in decreasing the activity of TNF- $\alpha$ which is considered as a strong factor in activation of tumor. That may be considered as a good hint to use this plant extract for medical application as shown in figure 3 . 


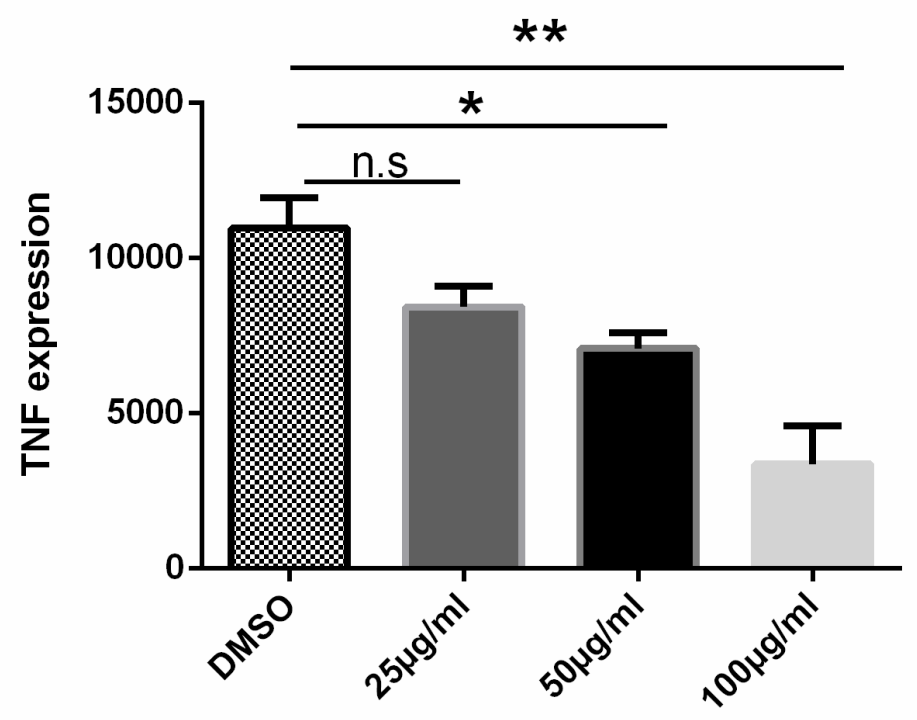

Conc.

Figure (3): reduction of TNF- $\alpha$ activity due to treatment of tumor cell line with plant extract. Cells were treated with different concentrations of the pl<nt $(25,50$ and $100100 \mu \mathrm{g} / \mathrm{ml})$ then, TNF - value was determined by Real time PCr. Data represents mean \pm SD of three independently repeated experiments. One way Anova followed by Dunnett's multiple comparison test using DMSO as a control used for statistical analysis of each time point separately

$(* * \mathbf{p} \leq \mathbf{0 . 0 1})$.

\section{Discussion}

Cancer is considered as the second-leading cause of mortality and morbidity and that pushed the researcher to discover an urgent way to develop (chemo) therapeutic interventions in order to help in restriction of cancer disease [21], because depending only on excision, surgery to treat cancer cases like breast cancer which is considered as one of the most common types of cancer in women as mentioned by Lopez group [22] is not enough to solve such disastrous problem. For this reason, the need comes to depend on another mean in order to help in surrounding the distribution of cancer.

Here in this study, the methanolic extract of Cardaria Graba was used to study the cytotoxic effect against different carcinogenic call lines like; HepG2, MCF7 and A375 cell line. Cardaria draba is considered as one of the most effective medical plant that showed different activities as a strong antimicrobial agent due to its ability to prevent the growth of some gram positive bacteria like Bacillus Spp.and gram negative bacteria like E.coli. Also, Sharifi- Rad found that this plant is considered as a substantial anti- oxidant agent on synthetic DPPH free radical from its leaf and seed extract and it has a fundamental anti- inflammatory activity[23].

It is well-known that natural plant extract plays important role in decreasing health problems which are associated with chronic diseases due to the presence of anti- oxidant components like; carotenoid, vitamins [24] because, there is an opposite relationship between the antioxidant compounds and human diseases like; cancer and other diseases[25].

The importance of previous finding which confirmed the role of Cardaria draba as a strong anti-oxidant pushed us to speculate if there is another biological effect which might help in restricting the growth of tumor. To do so, we checked if this plant has any cytotoxic effect on some type of tumor cell lines and if yes, we looked for the explanation of any mechanism which supports our results. 
Recently, studies proved that MTT assay is considered as an important method to check the cell viability, this method can detect survival rate the cells after the treatment with such active substances at specific time point [26]. The studies that talked about the cytotoxic activity of this plant extract is very rare, that pushed us to check cytotoxicity on different tumor cell lines and we got interesting results upon the treatment of those cell lines with our plant extract but with certain variation and the best one which had shown the lowest $\mathrm{IC}_{50}$ was HepG2 cells, for this reason; we chose this cell line to check the mechanism behind this cytotoxicity.

One of the most acceptable theories that give an explanation or correlation with cytotoxic effect on cell lines is apoptosis [27] , according to the findings of Looi; it is defined as one of the most complicated actions which triggered by molecules leading to activate caspase pathway in dependent or independent manner and caspase 9 is classified as an extrinsic pathway that trigger apoptosis. Indeed, caspases is related to the cysteine proteases category which is found either as initiator or executioner caspases and caspase 9 is being considered as initiator caspases [28] .

Depending on previous finding, we found that treatment with our plant extract induced apoptosis significantly, suggesting that Cardaria Graba plant extract has an effective apoptotic activity against cell lines.

Recently, it had been established that TNF- $\alpha$ is considered as an effective activator of the cancer as in breast cancer, this fact pushed us to check if the treatment of tumor cell line with our plant extract has a negative effect on the expression of TNF- $\alpha$. Our result showed that the incubation of tumor cell lines with Cardaria Graba reduced the expression of TNF- $\alpha$ significantly and this result could confirm the correlation between the reduction of TNF and our plant extract which has a strong antioxidant activity toward tumor cell lines as mentioned previously because, the plants that had shown antioxidant activity are able to inhibit TNF- $\alpha$ induced tumor in human cell line by blocking the activation of nuclear factor-kappa B (NF-kB) [29].

\section{Conclusion}

In conclusion this study report that the methanolic extract showed a significant antioxidant activity and cytotoxic activity against different cell lines like; A375, HepG2, MCF-7 cell line. The extract induces reduction in the acivity of TNF- $\alpha$ which is a causative agent for induction of tumor and at the same time activate Caspase-9 to induce apoptosis.

\section{References}

1. Hoary Cress.(2015) Weed Identification \& Information. Australian Weeds Committee.

2. Sharifi,R. J., Sharifi, R. M., Hoseini-Alfatemi S.M. and Iriti M. (2015) cytotoxic and antimicrobial activities of Saturejaintermedia CA Mey essential oil. International Journal of Molecular Sciences;16(8):17812-25.

3. Yu F., Takahashi T., Moriya J., Kawaura K., and Yamakawa J. (2006) Traditional Chinese medicine and Kampo: a review from the distant past for the future. J Int Med Res 34: 231-239.

4. Azaizeh H., Saad B., Khalil K. and Said O. (2006) The state of the art of traditional arab herbal medicine in the eastern region of the mediterranean: a review. Evid Based Complement Alternat Med 3: 229-235.

5. Cheng J.T. (2000) Review: drug therapy in Chinese traditional medicine. J Clin Pharmacol 40: 445-450.

6. Scartezzini P. and Speroni E. (2000) Review on some plants of Indian traditional medicine with antioxidant activity. J Ethnopharmacol 71: 23-43

7. Lev E. (2006) Ethno-diversity within current ethno-pharmacology as part of Israeli traditional medicine-a review. J Ethnobiol Ethnomed 2: 4.

8. Sharifi-Rad J., Hoseini-Alfatemi S.M., Sharifi-Rad M. and Setzer W.N.. (2015) Chemical composition, antifungal and antibacterial activities of essential oil from Lallemantia royleana (Benth. In Wall.) Benth. Journal of Food Safety;35(1):19-25. 
9. Vuorela P., Leinonen M., Saikku P., Tammela P., Rauha J-P. and Wennberg T., (2004) Natural products in the process of finding new drug candidate Current Medicinal Chemistry;11(11):137589.

10. Modi C., Mody S, Patel H, Dudhatra G., Kumar A. Awale M. (2012) Herbal antibacterials: a review Journal of Intercultural Ethnopharmacology;1(1):52-61.

11. Sharifi-Rad J., Miri A., Sharifi-Rad M., Sharifi-Rad M., Hoseini-Alfatemi S.M. and Yazdanpanah E. (2014) Antifungal and antibacterial properties of grapevine (Vitis vinifera L.) leaves methanolic extract from Iran-in vitro study. American- Eurasian Journal of Agricultural \& Environmental Sciences; $14: 1312-6$.

12. Rad J.S., Alfatemi S.M.H., Rad M.S. and Iriti M. (2013) In-vitroantioxidant and antibacterial activities of Xanthium strumarium L. extracts on methicillinsusceptible and methicillin-resistant Staphylococcus aureus. Ancient Science of Life;33(2):109.

13. Nair R. and Chanda S. (2008). Antimicrobial Activity of Terminalia catappa, Manilkara zapota and Piper betel Leaf Extract. Indian J Pharm Sci. 70(3): 390-393.

14. Alshanon, A., F. Hassan, A. Hameed and A. Al Saffar (2015). Synthesis, characterization, antioxidant activity and antitumor of some 2-amino-5-(3-nitro-phenyl)-1,3,4-thiadiazole derivatives. International Journal of Pharma Science, 1: 904-910.

15. Kathum O.A., Schräder T., Anhlan D., Nordhoff C., Liedmann S., Pande A., Mellmann A., Ehrhardt C., Wixler V., Ludwig S. (2016) phosphorylation of influenza A virus NS1 protein at threonine 49 suppresses its interferon antagonistic activity. Cell Microbiol.(6):784-91.

16. Dudek S.E., Luig C., Pauli, E.-K., Schubert U., and Ludwig S. (2010) The clinically approved proteasome inhibitor PS-341 efficiently blocks influenza A virus and vesicular stomatitis virus propagation by establishing an antiviral state. J Virol (84): 9439-51.

17. LooiC.Y., AryaA., CheahF.K., MuharramB., LeongK.H., MohamadK., WongW.F., RaiN.and, Mus tafaM.R.(2013)Induction of apoptosis in human breast cancer cells via caspase pathway by vernoda lin isolated from Centratherum anthelminticum (L.) seeds. PLoS One. 8(2):e56643.

18. Esmaeili M.A., Farimani M.M. and Kiaei M.(2014) Anticancer effect of calycopterin via PI3K/Akt and MAPK signaling pathways, ROS-mediated pathway and mitochondrial dysfunction in hepatoblastoma cancer (HepG2) cells. Mol Cell Biochem; 397(1-2):17-31

19. Harris, R., G. Alshafie, H. Abou-Issa and K. Seibert, (2000). Chemoprevention of breast cancer in rats by celecoxib, a cyclooxygenase 2 inhibitor. Cancer Research, 60: 2101-2103.

20. Piotrowska A., Wierzbicka J., Nadkarni S., Brown G., Kutner A. and Żmijewski M.A.(2016) Antiproliferative Activity of Double Point Modified Analogs of 1,25-

DihydroxyvitaminD ${ }_{2}$ Against Human Malignant Melanoma Cell Lines. Int J Mol Sci. pii: E76. doi: 10.3390/ijms17010076.

21. Taiwo B.J., Fatokun A.A., Olubiyi O.O., Bamigboye-Taiwo O.T., van Herdeen F.R. and Wright C.W. (2017) Identification of compounds with cytotoxic activity from the leaf of the Nigerian medicinal plant, Anacardium occidentale L. (Anacardiaceae).

22. Forouzanfar M.H., Foreman K.J., Delossantos A.M., Lozano R., Lopez A.D., et al. (2011) Breast and cervical cancer in 187 countries between 1980 and 2010 a systematic analysis. Lancet 378 : $1461-1484$.

23. Javad S., Seyedeh A., Majid S., Jaime A. Teixeira DS., Mehrad R. and Mehdi S. (2015) Evaluation of Biological Activity and Phenolic Compounds of Cardaria draba (L.) Extracts. J. Biol. Today's World; 4 (9): 180-189.

24. Duarte M.C.T., Figueira G.M., Sartoratto A., Rehder V.L.G. and Delarmelina C. (2005) AntiCandida activity of Brazilian medicinal plants. Journal of Ethnopharmacology;97(2):305-11. 
25. Morales G., Paredes A., Sierra P. and Loyola A. (2008) Antioxidant activity of 50\% aqueousethanol extract from Acantholippia deserticola. Biological Research.;41(2):151-5.

26. Chung Y. L., Aditya A., Foo K. C., Bushra M., Kok H. L., Khalit M., Won F.W., Nitika R. and Mohd R. M. (2013) Induction of Apoptosis in Human Breast Cancer Cells via Caspase Pathway by Vernodalin Isolated from Centratherum anthelminticum (L.) Seeds. Plos One, Volume 8: e56643.

27. Woo H.J., Jun do Y., Lee J.Y., Woo M.H., Yang C.H., et al. (2011) Apoptogenic activity of 2alpha,3alpha-dihydroxyurs-12-ene-28-oic acid from Prunella vulgaris var. lilacina is mediated via mitochondria-dependent activation of caspase cascade regulated by Bcl-2 in human acute leukemia Jurkat T cells. J Ethnopharmacol 135: 626-635.

28. Kumar S. (1999) Regulation of caspase activation in apoptosis: implications in pathogenesis and treatment of disease. Clin Exp Pharmacol Physiol 26: 295- 303.

29. Arya A., Achoui M., Cheah S.C., Abdelwahab S.I., Narrima P., et al. (2012) Chloroform Fraction of Centratherum anthelminticum (L.) Seed Inhibits Tumor Necrosis Factor Alpha and Exhibits Pleotropic Bioactivities: Inhibitory Role in Human Tumor Cells. Evid Based Complement Alternat Med 2012: 627256. 